\title{
Digital Audio Archiving in Community Radios of Kerala
}

\author{
Ritu Raveendran ${ }^{1}$, Dr. Muhammadali N. ${ }^{2}$

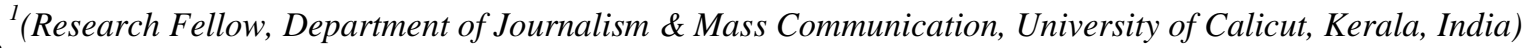 \\ ${ }^{2}$ (Assistant Professor, Department of Journalism \& Mass Communication, University of Calicut, Kerala, India)
}

\begin{abstract}
Sound archives are increasingly being viewed as tokens of cultural heritage from bygone eras. Novel techniques are explored for preserving and archiving these valuable records. The strong ethnical ties of community radio stations with the local community make it imperative to archive their audio contents as these are entwined with the knowledge, arts, culture and languages of indigenous people. This is particularly important because societies are fast embracing a single global culture and in the course, they lose their unique local traditions, dialects and arts. A scientific approach to archiving community radio contents is thus a social necessity to ensure people's easy access to these knowledge sources and convenient retrieval of information required. Archiving audio files as a responsibility to posterity is promoted by international agencies such as UNESCO. They propagate cost effective methods such as use of free and open source software for digitizing and archiving audio contents in community radio stations, fit to be emulated by similar organisations. This case study details the archiving practices of various community radio stations in Kerala.
\end{abstract}

\section{Keywords - Audio files, Community radio, Digital archiving, Greenstone, WINISIS}

\section{INTRODUCTION}

Communication has attained terrestrial scope from an era characterized by the limited communication happened among and between those who lived in close groups. This is essentially the result of man's constant strive to improve and develop his ability for communication, and his aversion to an isolated living. These days, hardly a day passes without each one of us, whether willingly or not, becoming a part of many social intercourses. The interdependence and harmony thus developed among the individuals as well as the society as a whole often raises certain disparities too. The imbalance in information flow and problems alongside is an issue still not rightly handled. Leaps in communication technologies alone cannot help solve this. This could be managed, to a certain degree, by ensuring the reach of required information to even the lower strata of society effectively and in time. Proper information dissemination can aid development of the society to which it is passed, uniting people towards a single goal, thus enabling true participation of citizens.

Assuring the reach of information and accessibility of knowledge to those, who otherwise are kept aloof from the privileges offered by advancements in technologies, is vital for development activities to happen in its right sense. M'Bow (Many Voices, One World, 1982) opines that personal enrichment as well as national advancement requires the development of a feeling of fellowship among people. This, to materialize, needs to resist the concentration of media from inhibiting the scope of various levels of communication and those factors which resist people's right to freedom of expression.

In most developing countries it is a mission unlikely to be fulfilled by only through public or private channels of communication. Propagation of local media such as community radio (CR) in these nations seem a logical solution to this dilemma. They enable the penetration of messages to the grass root level, where changes actually have to happen. The report of Mac Bride Commission (1980) and B.G. Verghese Committee (1977-78) have stressed the need for development of radio networks over television considering its reach to the remote areas.

\section{I.1 Community Radio in Kerala}

In the age of globalization, $\mathrm{CR}$ is the best mode to respond to the needs of the developing countries and the vast majority of deprived people living there. Community radio is the name given to the third tier system of broadcasting which is free from both government and private control. As the World Association of Community Broadcasters (AMARC) puts it, community radio democratizes communication and enables community participation in different forms suitable to different social contexts (Fraser \& Restrepo-Estrada, 2001). Fraser \& Restrepo-Estrada (2002) defines community radio as one managed by the community, and whose operations rely mainly on the community's own resources.

CR became a reality in India with the opening up of air waves after the Supreme Court judgment of 1995. In a country like India the existence of a third tier system of broadcasting is more of a necessity than a luxury. It enables horizontal communication rather than the traditional top down approach. The history of CR in

DOI: $10.9790 / 0837-2107074349 \quad$ www.iosrjournals.org $\quad 43$ |Page


Kerala is hardly a decade old. As on November 20, 2015 there are eight operational community radio stations (CRS) in Kerala (Website of the Ministry of Information \& Broadcasting, Govt. of India) which are managed by either educational institutions or NGOs. The relevance of CRS is that it can be adapted to suit and cater to the needs of the vast majority in accordance with the local culture, customs and dialects which change from region to region.

\section{I.2 ICT in Community Radio Stations}

The recent years show the proliferation of ICT (Information \& Communication Technology) in almost all fields of life. ICT in the field of mass communication help in easy documentation and knowledge sharing. UNESCO thrusts much on "facilitating and strengthening communication and information facilities at the local level as they offer basic tools for introducing and managing community centered development and change" (Rajasekharan \& Nafala, 2009). CR can enable public dialogue through which people can understand and define their needs thus paving way for capacity building and attainment of sustainable development. Only when effective public participation becoming a reality will people actuate the means to understand their requirements and seek the possibilities to acquire them.

Nowadays computers, other hardware(s) and suitable software(s) are used in almost all CRS as they ease the consolidation, management, storage and retrieval of the large number of audio contents, besides other documents, produced on a daily basis. Simplicity of installation, use and maintenance of hardware as well as software are critical for CRS.

\section{I.3 Digital Archiving of Sound}

Archiving is a centuries old tradition that has evolved much in course of time- from the materials preserved to the modes adopted. The influence of technology in easing the process besides making it lasting and foolproof is evident. Digital audio archiving is the process of building up of systematic digital audio collections which helps in easy searching and retrieval or for making them available on any required forum (Rajasekharan \& Nafala, 2009). The archiving of the broadcasted audio contents is a legal obligation as well as a selfregulatory mechanism, as observed by Panevska (Rajasekharan \& Nafala, 2009). BBC can be considered one among the pioneering organisation to devote a specialized department for archival purpose (P Harrison, 1987). Sound, images, words are all expressions of "intangible cultural heritage" ("Text of the Convention for the Safeguarding of the Intangible Cultural Heritage," 2003). UNESCO's urge to its member states "to assume responsibility of ensuring the identification, preservation and transmission to future generations of the digital heritage produced on their territory...to adapt regulations for national deposit and archival legislation...to promote open standards...in conjunction with the IT industry" ("Text of the draft: UNESCO resolution on Digital Preservation proposed by the Conference of Directors of National Libraries (CDNL) The Hague," 2001) indicates the importance of preserving heritage and adopting digital methods for it. Hill's (as cited in Collence Takaingenhamo Chisita \& Forbes. Z. Chinyemba, 2015) observation of sound and audiovisual archives as masts of intellectual and cultural capital supports UNESCO's view. Digital archiving is preferred as it prevents the quality degradation likely to arise with older documentation options, over years. Also, the business and economic impacts it has on an organisation cannot be overlooked (Queensland State Archives, 2010). For CRS, efficient space utilization coupled with minimal cost investment is important. Requirement to preserve all programmes for three months ("Policy Guidelines for setting up Community Radio Stations in India," n.d.), content sharing among stations and reuse of broadcast contents add complexity to the process.

\section{I.4 Audio Archiving Using Software}

Rapid obsolescence of technology is a major challenge for CRS. The stations often abstain from updating technologies owing to monetary reasons. Archiving requirements of CRS can be met by using free, stable and open source software. Greenstone, WINISIS or CDS/ISIS for Windows and GenISIS are those promoted by UNESCO for consolidating, building and managing digital audio libraries in CRS.

Developed by New Zealand Digital Library Project at the University of Waikato, Greenstone Digital Library Software is a powerful, free and open-source software for consolidating, managing and distributing digital documents. Simplicity of installation and use, highly customizable nature to meet the specific demands of users, the ability to support a variety of documents and file formats using plug-ins are advantages of Greenstone. It facilitates metadata browsing and full text search. It runs on both Windows and Unix. Efficient space utilization is ensured through compressed file storage. It can easily be managed by visually challenged users also, as a 'text only' interface can be created (Witten, Boddie, Bainbridge, \& McNab, 2000). The software is used by many important organisations around the world.

WINISIS developed by UNESCO is a versatile information storage and retrieval software. Simplicity of use, flexible nature, practicability to manage audio files stored in any storage media etc. make this software highly recommended for CRS because anyone with reasonable knowledge about computers can handle it. A 
handy front end for WINISIS archive can be created using GenIsisWeb software and WINISIS audio archive can be ported to CD-ROM with GenIsisCD software (Rajasekharan \& Nafala, 2009).

A facet of WINISIS and Greenstone, both interesting and relevant, is that the contents developed using the set can be exported to CD-ROMS or stored in computers as well. Archives created using Greenstone also facilitate publication on web. This is particularly useful in developing nations where the benefits of ICT is yet to reach a vast majority. There are wider options for storage and propagation of archives as well.

\section{RELATED STUDIES}

Collence Takaingenhamo Chisita \& Forbes. Z. Chinyemba (2015) illustrate sound and audiovisual archives as storage media of a nation's cultural as well as intellectual legacy, hence it is an obligation to preserve and pass them to future generations. Nations acquire status of knowledge economies and their innate open nature demands easy and open access to knowledge sources. Strengthening of ICT resources is thus the need of the hour. Making sound and audio visual archives easily accessible to users with varying digital literacy is a critical step. These challenges, as handled by the National Archives of Zimbabwe, are well described in this paper. Their principal conclusion is to increase investment in ICT and promote digitization of its archives thereby promoting their visibility, access and utilization beyond any confinement. There is urgency in promoting universal access to sound and audiovisual archives.

Nouza et al., (2012) describe a massive project launched for transcribing, indexing, archiving and enabling public access to the Czech Radio's 100.000 hours of spoken documents. Challenges such as huge volume of data involved, clumsy recordings of early eras, lexical variation of the language were faced with logical classification of data and systematic approach. The developed archive processing and accessing platform (APAP) is technologically complex, but simple at the user end. This has assisted in digitizing the audio heritage of Czech Radio.

Steenbakkers (2003) looks at how maintenance of large amount of digital data and permanent access to these can be guaranteed using ICT. Digital publications have undoubtedly improved the accessibility and life of such records, but have increased chances of loss too. Technology evolves, so does techniques. E-documentsbooks, sound or video- are vulnerable to rapid obsolescence of either the technology or the hardware and carrier medium involved. Numerous international projects are carried out to surmount the issues. The author concludes with the concepts of a 'Safe Place' (a digital archive) and 'Tools' (the functionalities and procedures required) as the keys for permanent archiving of digital records.

Ocana, Gomez-Cornejo Ortiz, \& Arraez, (2003) elucidate digital audio archiving of The Radio Nacional de España (RNE), now considered the chief sound archive of Spanish language in the world. The prime focus of the project was to preserve the content digitally, facilitate online multi user access and modification of current practices. Changes were incorporated in hardware and software and the envisioned goals were achieved. The project claim to be more successful when compared to similar ambitious ventures.

A coherent factor in these studies and projects undertaken is the intense efforts channelized in archiving sound files, in various parts of the world. Strengthening of ICT, digitalization of the existing archives for longevity, and facilitating easy user access were the core aims. It is evident from the studies that permeation of digital technologies can improve the current state of audio archiving.

\section{OBJECTIVES OF THE STUDY}

1. To understand how community radio stations in Kerala archive and manage their audio contents.

2. To examine the techniques and methods in practice and their fiscal implications.

3. To know if the professionals of CRS in Kerala are aware of free, open source software for archiving and managing their content.

\section{METHODOLOGY}

As the study demanded detailed account of archiving practices followed by each community radio station, case study method was adopted. A questionnaire seeking details regarding archiving, methods adopted, duration of storage, and storage devices used was sent to each radio station. In addition to the questionnaire, telephonic interviews were conducted with the people concerned

\section{CASES UNDER STUDY}

\section{Ahalia Voice 90.4, Palakkad}

Managed by Ahalia International Foundation, the station started broadcast in 2014 and currently air for 16 hours a day. Station Coordinator Mr. Ratheesh says the district's proximity to the state of Tamil Nadu has heavily influenced the native culture and the station, thus has an interesting array of programmes. There are dedicated programmes for Ayurveda propagation. So archiving is a regular practice at Ahalia. The station uses Steinberg Nuendo software for archival purpose. They follow date wise entry by programme names in a permanent digital location for maximum one year duration. 


\section{Community Radio Mattoli 90.4, Wayanad}

Licensed under Wayanad Social Service Society and credited for being the first community radio station in Kerala and the only one in Wayanad, Radio Mattoli airs for a total of 17 hours a day. Assistant Director of Programmes, Fr. Jaise Baby says that the importance of archiving is well understood by the station and over the years has developed a well-structured archive. The station's archive has a large and rare collection of programmes produced by members of various tribal communities, in their local dialects. This is very relevant in the present scenario where the younger generation of tribes has almost ceased the usage of native dialects and the languages are facing threat of being lost forever. The station uses indigenously developed software for archiving. Programmes are permanently stored in folders to reusable hard discs. The station is also equipped with RAID-Array $H D$ to combat data loss.

3. Global Radio 91.2, Alappuzha

This is the first and only community radio station relayed for Alappuzha. Promoted by Global Education Net, it currently airs for 15 hours a day and has educational, infotainment and local programmes. The Station Coordinator, Mr. Anil Amabalapuzha observes the need for an archive and has said that they are devising to build a well structured one. Currently, contents are categorized date wise, further by programme names and stored to dedicated computers and server for a period of six months.

\section{Janvani 90.8 FM, Kannur}

Janvani FM started broadcast in 2012 as the fifth CRS in the state. Managed by Academic and Technical Education Development Society (ATEDS), the station has extensive programmes meant for North Malabar. Mr. Nirmal Mayyazhi, the Station Director says they store all programmes for reference and reuse. He also mentioned their rising need to develop an archive as contents increase immensely on a day to day basis. The rich cultural content in programmes increases their relevance as reference materials too. Contents presently are stored by programme names in hard discs and preserved for minimum of one year.

5. Radio Benziger 107.8, Kollam

This CRS, established by Bishop Benziger Hospital started broadcast in 2010. Fr. Ferdinand Peter, the Station Director says apart from archiving their regular programmes, they maintain a voice bank of important personalities. They often reuse their archived programmes for reference. Programmes are stored as long as possible in CD-ROMs, hard discs and dedicated server under various sub categories. They report to rely on the technical support provided by parent organisation in case of data loss.

6. Radio Macfast 90.4, Tiruvalla

This is the first on campus community radio in Kerala launched in 2009 as the $46^{\text {th }}$ in the country. The station has an extensive archive, say the station officials. They use Station Playlist for archiving contents by programme name to dedicated hard discs. Detailed entry is made to a physical register also. They report to rely on recovery software for data retrieval if data loss occurs.

7. Radio DC 90.4, Thiruvananthapuram

Credited to be the first private CR in Kerala, the station is managed mainly by the staff and students of DCSMAT (DC School of Management and Technology). The station is equipped with digital recording facilities and airs for a total of 12 hours daily. This station has multiple storage locations and hence data loss is not a concern, says Mr. Sajikumar, the Station In-charge. They maintain physical registers with programme details, a practice since they started airing. Though software is not used for archival purpose, the station reports to depend on recovery software in case of data loss.

8. Radio Media Village 90.8, Changanassery

Managed by St. Joseph's College of Communication, the radio station started broadcast in 2012. It is the first community radio in the state run by a media college as well as the first in Kottayam district. As said by Station Coordinator, Mr. Vipinraj, they regularly update the archive as they air for 20 hours a day. There is strong capacity hardware to which date wise storage is done.

\section{DISCUSSION}

The following paragraphs detail software used for each purpose in CRS, digital storage devices used and CR professionals' awareness about free and open source software for audio archiving.

\section{VI.1 Software in use}

The inclusion of ICT has eased the functioning of CRS. Software(s) are used extensively for recording, editing and upload (play-out). It is interesting to note that though radio stations are primarily audio based establishments, automation of content management and archiving are still to be incorporated in the stations considered for the study. Also, the stations aren't prepared for retrieval of audio contents in case of data loss. While some said to depend on recovery software, other report to rely on technical support provided by parent organisation. The table details purpose- specific software used by various stations. 
Table 1: Software used for various purposes

\begin{tabular}{|c|c|c|c|c|c|c|}
\hline $\begin{array}{l}\text { Name of } \\
\text { Station }\end{array}$ & Recording & Editing & Play out & $\begin{array}{c}\text { Content } \\
\text { Management }\end{array}$ & Archiving & $\begin{array}{c}\text { Data } \\
\text { Recovery }\end{array}$ \\
\hline $\begin{array}{l}\text { Ahalia } \\
\text { Voice }\end{array}$ & $\begin{array}{l}\text { Steinberg } \\
\text { Nuendo }\end{array}$ & $\begin{array}{l}\text { Steinberg } \\
\text { Nuendo, } \\
\text { Sony Sound } \\
\text { Forge, } \\
\text { Adobe } \\
\text { Audition }\end{array}$ & $\begin{array}{l}\text { Station } \\
\text { Playlist } \\
\text { studio }\end{array}$ & Not given & $\begin{array}{l}\text { Steinberg } \\
\text { Nuendo }\end{array}$ & Nil \\
\hline $\begin{array}{l}\text { Radio } \\
\text { Mattoli }\end{array}$ & $\begin{array}{l}\text { Protools, } \\
\text { Sony Sound } \\
\text { Forge, } \\
\text { Adobe } \\
\text { Audition }\end{array}$ & $\begin{array}{l}\text { Protools, } \\
\text { Sony Sound } \\
\text { Forge, } \\
\text { Adobe } \\
\text { Audition }\end{array}$ & $\begin{array}{l}\text { Station } \\
\text { Playlist }\end{array}$ & Windows & $\begin{array}{l}\text { Custom } \\
\text { made }\end{array}$ & $\begin{array}{c}\text { Raid } \\
\text { Array HD }\end{array}$ \\
\hline $\begin{array}{l}\text { Global } \\
\text { Radio }\end{array}$ & $\begin{array}{l}\text { Sony Sound } \\
\text { Forge }\end{array}$ & $\begin{array}{l}\text { Sony Sound } \\
\text { Forge }\end{array}$ & $\begin{array}{l}\text { Station } \\
\text { Playlist }\end{array}$ & Nil & Nil & Nil \\
\hline Janvani & $\begin{array}{l}\text { Sony Sound } \\
\text { Forge }\end{array}$ & $\begin{array}{l}\text { Sony Sound } \\
\text { Forge }\end{array}$ & Nil & Nil & Nil & Nil \\
\hline $\begin{array}{l}\text { Radio } \\
\text { Benziger }\end{array}$ & Protools & Protools & $\begin{array}{l}\text { Station } \\
\text { Playlist }\end{array}$ & Nil & Nil & Nil \\
\hline $\begin{array}{l}\text { Radio } \\
\text { Macfast }\end{array}$ & Protools & Protools & Not given & Not given & $\begin{array}{l}\text { Station } \\
\text { Playlist }\end{array}$ & Nil \\
\hline Radio DC & $\begin{array}{l}\text { Sony Sound } \\
\text { Forge }\end{array}$ & $\begin{array}{l}\text { Sony Sound } \\
\text { Forge }\end{array}$ & Audacity & $\begin{array}{l}\text { Audacity, } \\
\text { Sony Sound } \\
\text { Forge }\end{array}$ & Nil & Nil \\
\hline $\begin{array}{l}\text { Radio } \\
\text { Media } \\
\text { Village }\end{array}$ & Protools & $\begin{array}{l}\text { Protools, } \\
\text { Nuendo, } \\
\text { Sony Sound } \\
\text { Forge, } \\
\text { Adobe } \\
\text { Audition }\end{array}$ & $\begin{array}{l}\text { Station } \\
\text { Playlist }\end{array}$ & Nil & Nil & Nil \\
\hline
\end{tabular}

VI.2 Storage choices

Multiple storage locations are used for two reasons- the limited capacity of storage devices and ensuring safe data retrieval in case one device/ location malfunction. The table shows the preferred storage locations of various stations.

Table 2: Digital Storage Devices in use

\begin{tabular}{|l|c|c|c|c|c|c|c|}
\hline \multicolumn{1}{|c|}{ Stations } & $\begin{array}{c}\text { Duration } \\
\text { of storage }\end{array}$ & Computer & $\begin{array}{c}\text { External } \\
\text { hard disc }\end{array}$ & $\begin{array}{c}\text { CD- } \\
\text { ROM }\end{array}$ & Server & $\begin{array}{c}\text { Google } \\
\text { drive }\end{array}$ & Other \\
\hline Ahalia Voice & One year & Not using & Not using & $\begin{array}{c}\text { Not } \\
\text { using }\end{array}$ & $\begin{array}{c}\text { Not } \\
\text { using }\end{array}$ & $\begin{array}{c}\text { Not } \\
\text { using }\end{array}$ & $\begin{array}{c}\text { Permanent } \\
\text { source }\end{array}$ \\
\hline $\begin{array}{l}\text { Radio } \\
\text { Mattoli }\end{array}$ & Permanent & Not using & Using & $\begin{array}{c}\text { Not } \\
\text { using }\end{array}$ & $\begin{array}{c}\text { Not } \\
\text { using }\end{array}$ & $\begin{array}{c}\text { Not } \\
\text { using }\end{array}$ & Not using \\
\hline Global Radio & $\begin{array}{c}\text { Min. for six } \\
\text { months }\end{array}$ & Using & Not using & $\begin{array}{c}\text { Not } \\
\text { using }\end{array}$ & Using & $\begin{array}{c}\text { Not } \\
\text { using }\end{array}$ & Not using \\
\hline Janvani & $\begin{array}{c}\text { More than } \\
\text { one year }\end{array}$ & Not using & Using & $\begin{array}{c}\text { Not } \\
\text { using }\end{array}$ & $\begin{array}{c}\text { Not } \\
\text { using }\end{array}$ & $\begin{array}{c}\text { Not } \\
\text { using }\end{array}$ & Not using \\
\hline $\begin{array}{l}\text { Radio } \\
\text { Benziger }\end{array}$ & $\begin{array}{c}\text { No specific } \\
\text { period }\end{array}$ & Not using & Using & Using & Using & $\begin{array}{c}\text { Not } \\
\text { using }\end{array}$ & Not using \\
\hline $\begin{array}{l}\text { Radio } \\
\text { Macfast }\end{array}$ & $\begin{array}{c}\text { No specific } \\
\text { period }\end{array}$ & Not using & Using & $\begin{array}{c}\text { Not } \\
\text { using }\end{array}$ & $\begin{array}{c}\text { Not } \\
\text { using }\end{array}$ & $\begin{array}{c}\text { Not } \\
\text { using }\end{array}$ & Not using \\
\hline Radio DC & $\begin{array}{c}\text { No specific } \\
\text { period }\end{array}$ & Using & Using & Using & Using & Using & DC's Portal \\
\hline $\begin{array}{l}\text { Radio Media } \\
\text { Village }\end{array}$ & $\begin{array}{c}\text { No specific } \\
\text { period }\end{array}$ & Not using & Not using & $\begin{array}{c}\text { Not } \\
\text { using }\end{array}$ & $\begin{array}{c}\text { Not } \\
\text { using }\end{array}$ & $\begin{array}{c}\text { Not } \\
\text { using }\end{array}$ & $\begin{array}{c}\text { High capacity } \\
\text { hardware }\end{array}$ \\
\hline
\end{tabular}

Owing to their easy availability, better capacity, and portability, external hard discs are the most preferred devices for storing archived contents. Though Google drive, portals etc are more reliable and convenient, they may be inaccessible during power failures. 


\section{VI.3 Awareness about Free and Open Source Software}

Enquiry about free and open source software such as Greenstone and WINISIS, for digital archiving revealed that six out of eight stations were unaware of these. Radio Benziger and Radio Mattoli, though using other methods, were aware of Greenstone.

Certain technical difficulties occurred during the initial phase refrained us from continuing with Greenstone. (Official, Radio Benziger)

The inhibition in migrating from the existing familiar methods and software keeps Mattoli from implementing Greenstone. We use indigenously developed software tailored to fit our requirements and the staff as well as volunteers is well versed with it. (Fr. Jose Kavunkal, Assistant Director Broadcast, Radio Mattoli).

Table 3: Awareness about open source software

\begin{tabular}{|l|c|c|c|}
\hline \multicolumn{1}{|c|}{ Stations } & $\begin{array}{c}\text { Aware of open source } \\
\text { software }\end{array}$ & $\begin{array}{c}\text { Use open source } \\
\text { software }\end{array}$ & Reason \\
\hline Ahalia Voice & No & No & Unaware \\
\hline Radio Mattoli & Yes & No & Haven't implemented \\
\hline Global Radio & No & No & Unaware \\
\hline Janvani & No & No & Initial technical issue \\
\hline Radio Benziger & Yes & No & Unaware \\
\hline Radio Macfast & No & No & Unaware \\
\hline Radio DC & No & No & Unaware \\
\hline Radio Media Village & No & & \\
\hline
\end{tabular}

\section{FINDINGS}

1. Archiving methods of CRS in Kerala are relatively old when compared to the prevailing practices in the field. Keeping abreast of the technological advancements may be impossible for CRS which function on limited funds. Still, archiving as an obligation to future is still not rightly understood by all stations. Automation of archiving is yet to be implemented in CRS in Kerala except Ahalia Voice, Radio Macfast and Radio Mattoli.

2. Fiscal implication is negligible for the stations with their current archival practices, and involving manageable amount of contents. Stations rely mostly on removable hard discs as these are reusable and economical. Though free storage is possible with Google drive, it is not much utilized. Stations which use portals for storing audio archives aren't much financially affected because their parent organisation provides the required infrastructure.

3. Most of the CR professionals in Kerala are not aware of free, stable open source software for digital archiving. The two CRS Radio Mattoli and Radio Benziger which knew about these, use different software and methods for archiving their audio contents.

\section{RECOMMENDATIONS}

1. CR professionals need to be sensitized about the significance of audio documents as assets to the cultural capital of a community. Their proper accumulation, classification, storage, access and retrieval are to be encouraged on a long term basis. Archiving has to be more of a practice than a legal obligation.

2. If long term or permanent archiving is envisioned by the CRS in Kerala, with their existing techniques, costs are likely to shoot up. Storage devices, space to contain them, maintenance of appropriate condition for their preservation, repair and replacement, updating to newer techniques, and most importantly the requirement of professional help for the purpose are some of the necessities to arise alongside. Switching to digital methods is a cost effective solution for this.

3. Digital audio libraries are to be made an integral part of CRS. Free, open source software such as Greenstone, WINISIS etc. can aid CRS to develop a library with no additional cost involvement. Digitization of audio and documents of various formats is possible using the same software. This considerably cuts down cost on maintaining hard copies of all documents, additional storage locations and devices.

4. A nationwide study will explore more glaring realities prevailing in the field, particularly regarding the minimal use of digital technology by the professionals in community radio stations.

5. As it is mandatory to store the audio content for a fixed period of time and the archiving will contribute to the history of local culture and regional language, government agencies concerned can take policy decision on enforcing digital archival mechanism in all licensed community radio stations especially when free and open software are available from authentic source like UNESCO and the University of Waikato. 


\section{CONCLUSION}

The preservation of sounds in future is based on a strategy, rather than a format (Brylawski et al., 2015). There is no dearth of challenges in sound archiving- fiscal implications, technological issues and data loss, improperly trained professionals- to mention a few. But, such impediments should not give way for the loss of precious audio files which may not be available for a second time. For CRS, this is particularly important as their programmes are largely community oriented. Increasing significance of audio documents as pillars of culture, and knowledge sources render their archiving, storage, and convenient retrieval an obligation. Creation and maintenance of a digital audio library is the best possible solution to meet these requirements. A digital library provide comprehensive, well structured arrangement of digital documents (here audio files) with easy retrieval options, thus ensuring extensive reach and penetration of messages to a larger population.

\section{REFERENCES}

[1] Many Voices, One World (New Delhi: Oxford \& IBH Publishing Co., 1982).

[2] C. Fraser and S. Restrepo-Estrada, Community Radio Handbook. (UNESCO, 2001) http://www.unesco.org/webworld/publications/community_radio_handbook.pdf. Retrieved Mar 20, 2013.

[3] C. Fraser and S. Restrepo-Estrada, Community Radio for Change and Development, Development, 45(4), 2002, 69-73.

[4] K. Rajasekharan and K.M. Nafala, Digital Archiving of Audio Content Using WINISIS and Greenstone Software: A Manual for Community Radio Managers. Edited by Bimal Kanti Sen. (New Delhi: UNESCO, 2009) http://greenstonesupport.iimk.ac.in/Documents/digital_archiving_en.pdf.

[5] H. P. Harrison, The Archival Appraisal of Sound Recordings and Related Materials: A RAMP Study with Guidelines. (UNESCO, February 1987).

[6] Text of the Convention for the Safeguarding of the Intangible Cultural Heritage. (UNESCO, October 2003). http://www.unesco.org/culture/ich/en/convention. Retrieved June 15, 2016.

[7] Text of the Draft: UNESCO Resolution on Digital Preservation Proposed by the Conference of Directors of National Libraries (CDNL) (The Hague: UNESCO, June 2001). http://www.aes.org/technical/documentDownloads.cfm?docID=107. Retrieved June 15, 2016.

[8] C.T. Chisita, and F.Z. Chinyemba. Towards an Open and Accessible Sound and Audiovisual Archives: Case Study of Zimbabwe, IASA Journal, Vol. 45, 2015.

[9] Queensland State Archives, Digital Archiving Discussion Paper: Informing an Approach to the LongTerm Management and Preservation of Government Digital Records. (Queensland State Archives, May 2010). http://www.archives.qld.gov.au/Recordkeeping/GRKDownloads/Documents/QSA-DigitalArchiving-Discussion-Paper.pdf. Retrieved Mar 20, 2015.

[10] Policy Guidelines for Setting up Community Radio Stations in India. Ministry of Information \& Broadcasting, Govt. of India, n.d. http://mib.nic.in/WriteReadData/documents/c1.pdf. Retrieved June 20, 2016.

[11] I.H.Witten, S.J. Boddie, D. Bainbridge \& R.J. McNab, Greenstone: A Comprehensive Open-Source Digital Library Software System, Proc Fifth ACM Conference on Digital Libraries, ACM, 2000, 113121. http://dl.acm.org/citation.cfm?id=336650. Retrieved Feb 26, 2015.

[12] J. Nouza, K. Blavka, P. Cerva, J. Zdansky, J. Silovsky, M. Bohac \& J. Prazak. Making Czech Historical Radio Archive Accessible and Searchable for Wide Public, Journal of Multimedia, 7(2), April 1, 2012. doi:10.4304/jmm.7.2.159-169.

[13] J. Steenbakkers, Permanent Archiving of Electronic Publications: Research \& Practice, International SummerSchoolontheDigitalLibrary,2003. http://www.kb.nl/sites/default/files/docs/summerschoolticer2003.pdf.

[14] A.C. Ocana, J.C. Gomez-Cornejo Ortiz, and M.J. Rodeno Arraez. The Radio Nacional de España Sound Archive Preservation, Proc From information to knowledge: 7th ICCC/IFIP International Conference on ElectronicPublishing,UniversidadedoMinho,Portugal,2003. http://elpub.scix.net/data/works/att/0319.content.pdf. Retrieved Mar 15, 2015.

[15] Brylawski, Samuel, Maya Lerman, Robin Pike, and Kathlin Smith, eds. ARSC Guide to Audio Preservation. (Association for Recorded Sound Collections, the Council on Library and Information Resources, and The Library of Congress, 2015). 